\title{
Immobilization kinetics and mechanism of bovine serum albumin on diatomite clay from aqueous solutions
}

\author{
Mehmet Harbi Çalımlı ${ }^{1}$ Özkan Demirbaş ${ }^{2} \cdot$ Aysenur Aygün $^{3} \cdot$ Mehmet Hakkı Alma ${ }^{4} \cdot$ Mehmet Salih Nas $^{4}$. \\ Fatih Şen ${ }^{3}$ (1)
}

Received: 11 September 2018 / Accepted: 16 October 2018 / Published online: 26 October 2018

(c) The Author(s) 2018

\begin{abstract}
In this research, adsorption properties of bovine serum albumin (BSA) on diatomite clay, which is an oxide mineral, were studied as a function of BSA, sodium phosphate buffer and protein concentration and $\mathrm{pH}$ and the thermodynamic parameters of adsorption process were investigated. The BSA adsorption experiment onto diatomite clay indicated that the BSA solution reached the maximum adsorption value at $\mathrm{pH}$ 5.5. It was observed that the maximum adsorption capacity (qm) of the data obtained from the adsorption studies showed a great dependence on $\mathrm{pH}$. The maximum amount of adsorption in adsorption experiments can be considered as points where the electrostatic interaction for $\mathrm{pH}$ is appropriate. Both structural and electrostatic interaction in regions outside of the isoelectric point may have caused a decrease in BSA absorbance. The structural influences were associated with different conformational states that while BSA molecules accept changes with $\mathrm{pH}$, electrostatic effects can be observed in BSA molecules behaved like soft particles. In this case, it is not possible to explain the independence of the $\mathrm{qm}-\mathrm{pH}$ curves of the amount of adsorption. The protein molecules at this point are very stable. Because this value is close to the isoelectric point of serum albumin. The surface structural change of BSA and diatomite clay was studied. For this, Fourier transform infrared spectroscopy (FTIR) spectroscopy values were compared before and after the experiment. The diatomite samples used as support material were characterized by FTIR, scanning electron microscopy, thermogravimetric analysis and Brunauer Emmett-Teller surface area analysis. The thermodynamic functions such as enthalpy, entropy, Gibbs free energy and activation energy were investigated in their experimental work. The thermodynamic parameters such as Gibbs free energy $\left(\Delta G^{*}\right), E_{\mathrm{a}}, \Delta H^{*}$ and $\Delta S^{*}$ were calculated as $-67.45,15.41,-12.84 \mathrm{~kJ} \mathrm{~mol}^{-1}$ and $-183.28 \mathrm{~J} \mathrm{~mol}^{-1} \mathrm{~K}^{-1}$ for BSA adsorption, respectively. We can deduce that the adsorption process from the data obtained from the thermodynamic parameters is spontaneous and exothermic. The adsorption of the process was investigated using Eyring and Arrhenius equations, and its adsorption kinetic found to be coherent with the pseudo-second-order model. As a result, we reached that the diatomite clay is a suitable adsorbent for the BSA. Experimental results showed that diatomite clay has the potency to be used for rapid pretreatment in the process of identifying proteins.
\end{abstract}

keywords Adsorption $\cdot$ Diatomite clay $\cdot$ Thermodynamic $\cdot$ Protein

Mehmet Salih Nas

msnas34@gmail.com

Fatih Şen

fatihsen1980@gmail.com

1 Tuzluca Vocational High School, Igdir University, Igdir, Turkey

2 Department of Chemistry, Faculty of Science and Literature, University of Balikesir, Balikesir, Turkey

3 Sen Research Group, Department of Biochemistry, Faculty of Arts and Science, Dumlupınar University, Evliya Çelebi Campus, 43100 Kutahya, Turkey

4 Department of Environmental, Faculty of Engineering, University of Igdir, Igdir, Turkey

\section{Introduction}

The biotechnological and nanotechnological advances have recently begun to be used in many areas such as biosensors, artificial implants, nanocatalysts, purification strategies and drug delivery system (Demirci et al. 2016; Ayranci et al. 2017a, b; Sahin et al. 2018; Karatepe et al. 2016; Aday et al. 2016a, b; Yildiz et al. 2016a, b, c, d, e, 2017a, b, c; Erken et al. 2015; Baskaya et al. 2017a, b; Celik et al. 2016a, b, c; Abrahamson et al. 2013; Demir et al. 2017a, b; Erken et al. 2016a, b; Akocak et al. 2017; Eris et al. 2018a, b, c; Esirden et al. 2015; Goksu et al. 2016a, b, c, 2017; Sen et al. 
2007, 2011a, b, 2012a, b, c, 2013a, b, c, 2014a, b, 2017a, b, c, d, e, f, 2018a, b; Mittal et al. 2010; Gupta et al. 2011, 2014a, b, 2015; Saleh and Gupta 2011, 2012a, b, 2014; Khani et al. 2010; Saravanan et al. 2013a, b, c, d, e, 2015a, b, 2016a, b; Devaraj et al. 2016; Gupta and Saleh 2013; Erkan et al. 2006; Bozkurt et al. 2017; Pamuk et al. 2015; Sahin et al. 2017; Dasdelen et al. 2017; Iverson et al. 2013; Koskun et al. 2018; Sen and Gokagac 2007, 2008, 2014; Gezer et al. 2017; Giraldo et al. 2014; Ahmaruzzaman and Gupta 2011; Mohammadi et al. 2011; Robati et al. 2016; Ghaedi et al. 2015; Asfaram et al. 2015; Topuz et al. 2010; Zhang et al. 2013). In biosensor systems, protein molecules are extremely effective in transduction events and the structural properties of adsorbed protein molecules are particularly influenced by the biocompatibility of the materials. The besides protecting the structure of protein molecules practically in adsorption processes furthermore, new changes in protein structure to perform adsorption are crucial to understand the structural changes in adsorption induction (Celik et al. 2016d; Giacomelli and Norde 2001). The interaction of any support molecules of biomolecules has intensively worked in the past (Norde et al. 2000; Rigou et al. 2006). The bovine serum albumin (BSA), which is used as a biomolecule, has spherical dimensions of about $4 \mathrm{~nm} \cdot 4 \mathrm{~nm}$. $14 \mathrm{~nm}$ (Violante et al. 1995). The BSA represents 52-62\% of total protein in blood plasma (McClellan and Franses 2003). The most important physiological characteristic of serum albumin is to play a role in adjusting osmotic pressure and blood $\mathrm{pH}$, and BSA also plays a role in the transport of compounds such as fatty acids, metals, amino acids, steroids and drugs (Brandes et al. 2006). The isoelectric point of BSA is at $\mathrm{pH}$ 4.7. We can take it that the $\mathrm{pH}$ solutions prepared on BSA isoelectric point are loaded with negative (Huang and Kim 2004). The BSA molecules have the ability to bind especially strongly negatively charged support materials. For this reason, it takes an active role in transportation (Kudelski 2003). Protein adsorption is important from the complex nature of the system when viewed from a more fundamental perspective and ideally, a protein adsorption can be affected by $\mathrm{pH}$, ionic strength, protein concentration and buffer solution states. For this reason, protein adsorption studies have recently been extensively studied on experimental conditions (Hu and Su 2003; Hunter 1999). The diatomite consists of siliceous rocks in sedimentary construction of a small part of crystalline material $\left(\mathrm{SiO}_{2} \cdot \mathrm{nH}_{2} \mathrm{O}\right)$ in the form of an amorphous silica. It possesses extremely important physical and chemical properties such as high permeability large pore structure, low thermal conductivity, wide surface area and small particle size. The diatomite clay is found in high quantities in Turkey and in various regions of the world (Vroman and Adams 1969; Khraisheh et al. 2004). Diatomite clay is a micro/nanostructured material that is derived from sedimentary silicon, low cost, harmless and environmentally sensitive and natural (Sheng et al. 2009). The purpose of this work is to determine the physicochemical adsorption kinetics of the BSA molecule on diatomite clay under certain conditions. In this sorption process, many experimental parameters were analyzed including the $\mathrm{pH}$, ionic strength, protein concentration and buffer solution concentration. The kinetic analysis studies were carried out after the amount of BSA adsorbed on the diatomite clay was determined. Thermodynamic parameters such as Gibbs free energy $\left(\Delta G^{*}\right)$, $E_{\mathrm{a}}, \Delta H^{*}$ and $\Delta S^{*}$ were calculated. The purpose of this work was to study the kinetics and mechanism of adsorption of BSA on diatomite clay as support material under optimum experimental conditions. Thus, this investigation is aimed at to study the kinetics and dynamics of adsorption of BSA on diatomite clay.

\section{Experimental}

\section{Materials and methods}

The bovine serum albumin (BSA) was purchased from Sigma (with purity $>99.9 \%$, USA). In this research, the sample of diatomite clay and some analyzes were performed for its characterization. The bovine serum albumin used in the study was purchased from Sigma. The solvents and chemicals were purchased from Merck AG (Darmstadt, Germany). The diatomite clay was obtained from the Seller Company. The SEM (SCM 5000) was used to clarify the microstructural and morphological structure of the clay sample. The water was passed from Milli-Q system and distilled two times. The elements contained in the clay sample and the percentages of these elements are given in Table 1. The BET $\mathrm{N}_{2}$ (Micromeritics Flow Sorb II 2300) was used to investigate the specific surface area of the clay, and some properties of the diatomite clay are given in Table 2 . The agitation was done for $120 \mathrm{~min}$. The adsorption experiment was performed in the main parameters at $\mathrm{pH} 7,298 \mathrm{~K}$ and $\left.0.5 \mathrm{~g} \mathrm{~L}^{-1}\right) . \mathrm{NaOH}$ $(0.05 \mathrm{~N})$ and $\mathrm{HCl}(0.05 \mathrm{~N})$ were used to adjust $\mathrm{pH}$. Four milliliters of samples was taken from the sample to get measure at certain time intervals during the experiment. The centrifugation was performed at $8000 \mathrm{rpm}$ for $5 \mathrm{~min}$, and then
Table 1 The elements that the sample contains and their percentage

\begin{tabular}{ll}
\hline Elements & Percentage (\%) \\
\hline $\mathrm{Si}$ & 48.4 \\
$\mathrm{O}$ & 36.8 \\
$\mathrm{Al}$ & 9.9 \\
$\mathrm{Mg}$ & 1.4 \\
$\mathrm{Fe}$ & 2.2 \\
$\mathrm{~K}$ & 0.7 \\
$\mathrm{Ca}$ & 0.6 \\
\hline
\end{tabular}


Table 2 Some properties of the clay sample used in the work

\begin{tabular}{ll}
\hline Parameters & Value \\
\hline Color & White \\
Particle size $(\mu \mathrm{m})$ & $(49-105)$ \\
$\mathrm{pH}$ & 6.63 \\
Specific surface areas $\left(\mathrm{m}^{2} \mathrm{~g}^{-1}\right)$ & \\
Single point + specific surface area & $1.657 \mathrm{e}+02 \mathrm{~m}^{2} \mathrm{~g}^{-1}$ \\
Multipoint + specific surface area & $1.672 \mathrm{e}+02 \mathrm{~m}^{2} \mathrm{~g}^{-1}$ \\
\hline
\end{tabular}

concentrations of the residual serum albumin were determined using a UV-Vis spectrophotometer (Carry 1EUVVIS). The amount of serum albumin adsorbed on diatomite clay surface was found by using Eq. (1) (Lemonas 1997).

\section{Adsorption experiments}

The protein adsorption experiments were performed in the water bath to adsorption study of BSA on diatomite clay. The experiments were performed using protein mechanic stirrer by diatomite clay samples with $100 \mathrm{ml}$ aqueous solution at various concentrations $\left(0.10-0.35 \mathrm{~g} \mathrm{~L}^{-1}\right)$, sodium phosphate buffer concentrations $\left(2.5 \cdot 10^{-2}-7.5 \cdot 10^{-2} \mathrm{~mol} \mathrm{~L}^{-1}\right)$, $\mathrm{pH}(5.5-9)$ and temperature (288-318 K). The suspensions used in the experiment was stirred at $288 \mathrm{~K}$ and 700 (rpm) for $4 \mathrm{~h}$ in an incubator-shaker. In adsorption experiments, blind experiments were performed under the same experimental conditions. Every protein adsorption experiment was repeated three times. The since the data obtained from the study were very close to each other, the averages were taken. The concentration of the protein molecule in the initial solutions and the post-adsorption concentration were carried out by UV-Vis spectrophotometer.

$q_{\mathrm{t}}=\frac{\left(C_{\mathrm{o}}-C_{\mathrm{t}}\right) V}{m}$

where in this equation, $q_{\mathrm{t}}$ is enzyme concentration, $\mathrm{m}$ is the mass of the clay, $V$ is the volume of the mixture, $C_{\mathrm{o}}$ is the concentration of enzyme solution and $C_{\mathrm{t}}$ is at any time concentration of enzyme solution (Lemonas 1997).

\section{Results and discussion}

\section{Protein adsorption experiments}

The changing adsorption kinetic rate with the initial concentration of the bovine serum albumin is shown in Fig. 1. It is observed that the adsorption rate increases with increasing bovine serum albumin initial concentration. It can be seen in Fig. 1 that when the initial of concentration bovine serum albumin increased from 0.25 to $0.75 \mathrm{~g} \mathrm{~L}^{-1}$, the absorption of the protein increased from 0.077 to $0.1748 \mathrm{mg} \mathrm{g}^{-1}$. The adsorption effect of the initial $\mathrm{pH}$ of BSA on diatomite clay the amount of BSA was investigated by changing under constant process parameters. As shown in Fig. 1a, the increase in $\mathrm{pH}$ decreases the amount of adsorption of protein molecules. The zero-load point, in which hydroxyl and proton ions are equal, has an important effect on the pH effect, especially in protein adsorption processes (Akkuş 2006). Because the net charge is zero at the isoelectric point in which enzymes or proteins have a very stable structure. The protein is more active at this point or near these points, preserving their
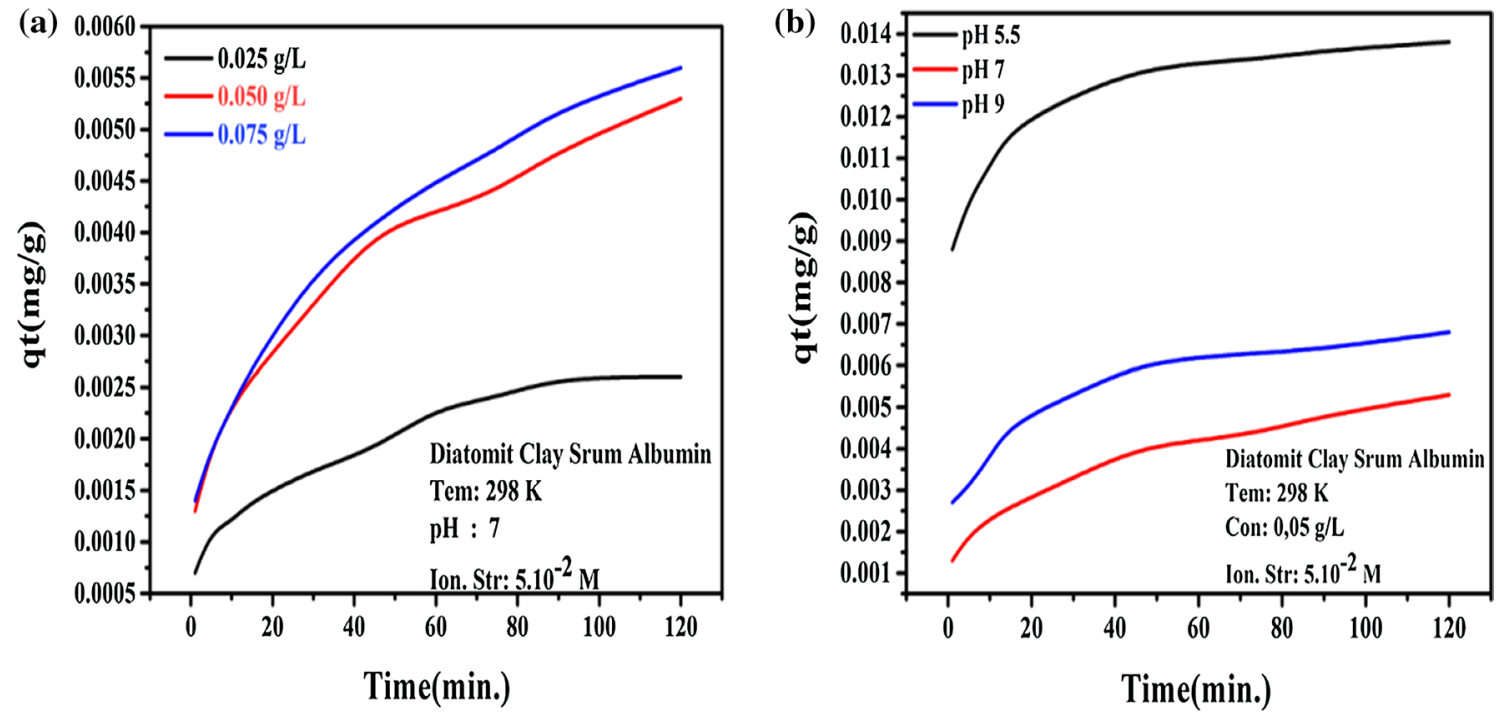

Fig. 1 The effect of a initial enzyme concentration and $\mathbf{b} \mathrm{pH}$ to the adsorption rate of bovine serum albumin (BSA) on diatomite clay

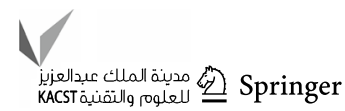



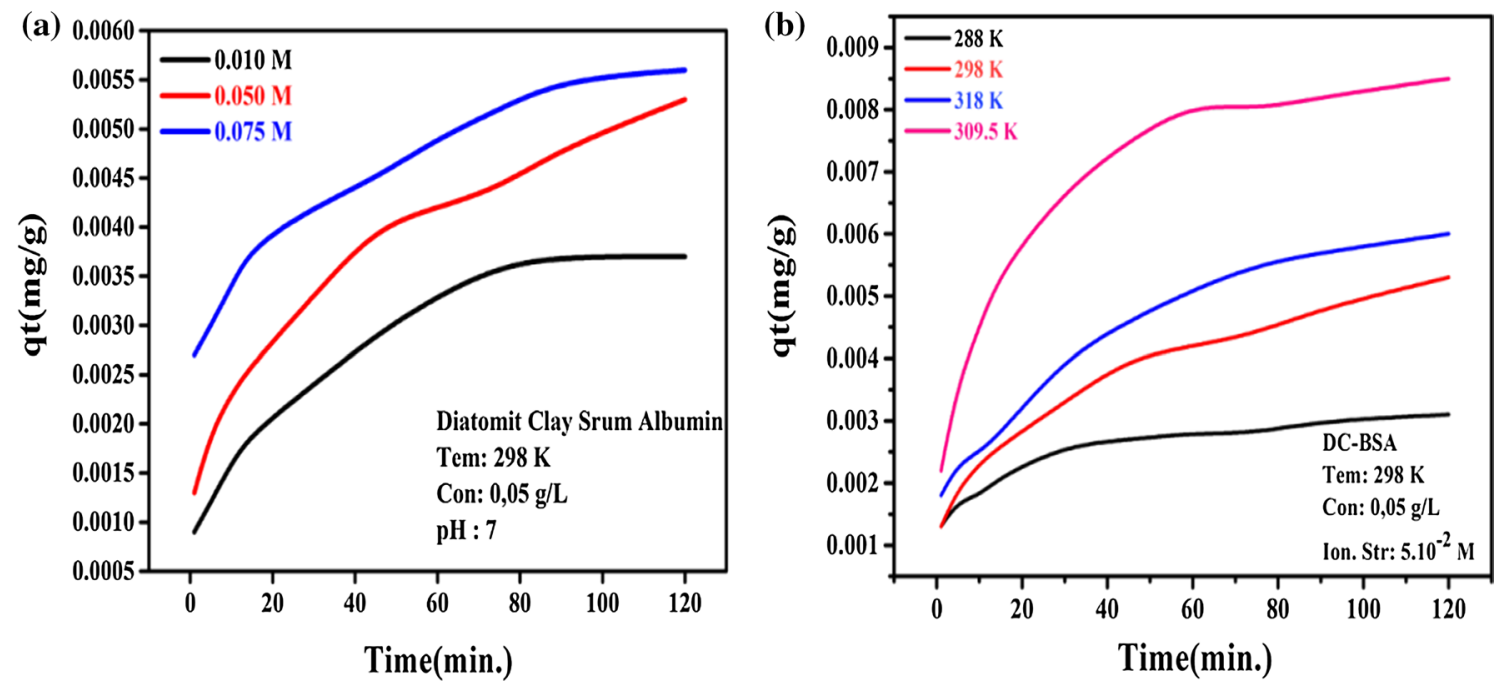

Fig. 2 The effect of $\mathbf{a}$ ionic strength and $\mathbf{b}$ temperature to the adsorption rate of BSA on diatomite clay

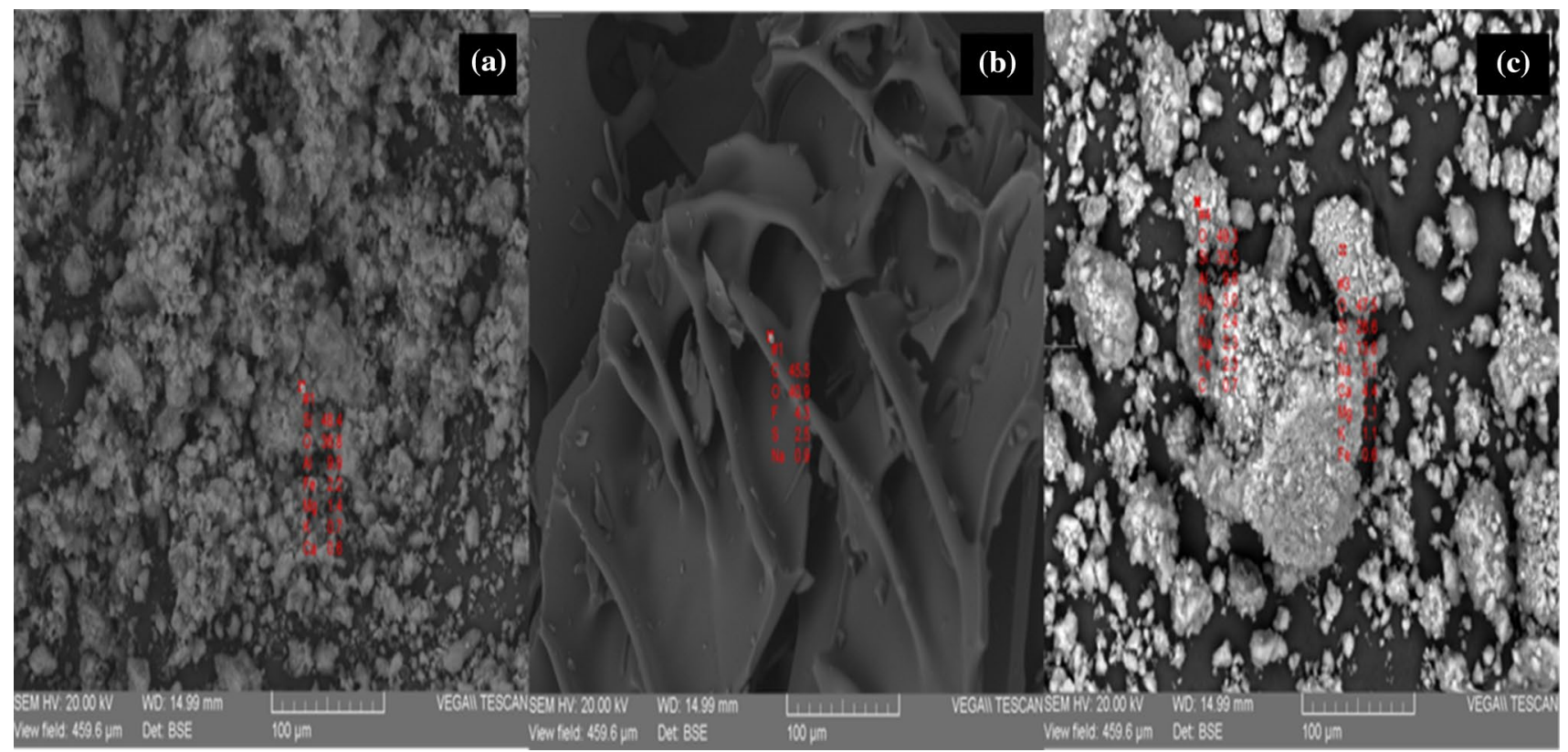

Fig. 3 SEM microphotographs of DC (a), BSA (b) and BSA adsorbed DC (c) after $120 \mathrm{~min}$

three-dimensional structure. But these structures will start to decompose stable values below or above the isoelectric point (Fig. 2). This situation adversely affects the amount of adsorption (Hunter 1999). Loads on the surface of proteins that are biomolecules are not homogeneous. When the $\mathrm{pH}$ of the solution changes, the charge on the protein surface changes. The $\mathrm{pH}$ values below the isoelectric point of the BSA are usually positively charged, and the $\mathrm{pH}$ values above the isoelectric point of the BSA are usually negatively charged (Doğan et al. 2006). The isoelectric point of the BSA used as an adsorbent in the work is about pH 4.7 (Mansch and
Chapman 1996). The adsorption of BSA onto diatomite clay reached a maximum value of $\mathrm{pH}$ 5.5. Therefore, at this $\mathrm{pH}$, the interaction between serum albumin and diatomite clay is greater. The same is the enzyme lipase which biomolecules have negative charges increases at $\mathrm{pH}$ values above the isoelectric point leads to an increase in negative charge in the surface of krill clay as it. Demirbaş et al. stated this situation in a nice way (Tasman and Ajaeger 1998). SEM microphotographs of DC, BSA and BSA adsorbed DC after 120 min are shown in Fig. 3. Besides, as shown in Fig. 4, the increase in the amount of sodium phosphate salts resulted in an increase 


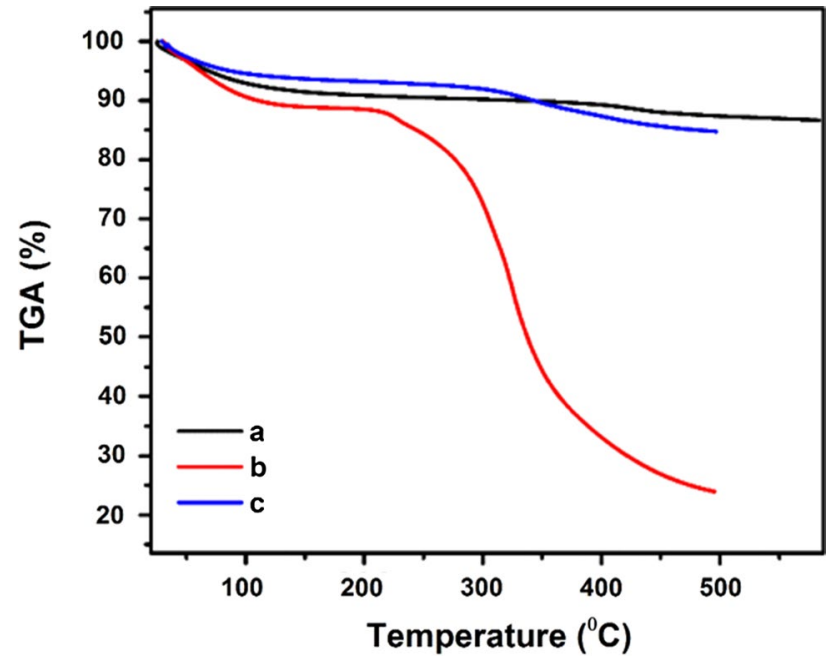

Fig. 4 Thermogravimetric analyses of DC (a), BSA (b) and BSA adsorbed DC (c) after $120 \mathrm{~min}$

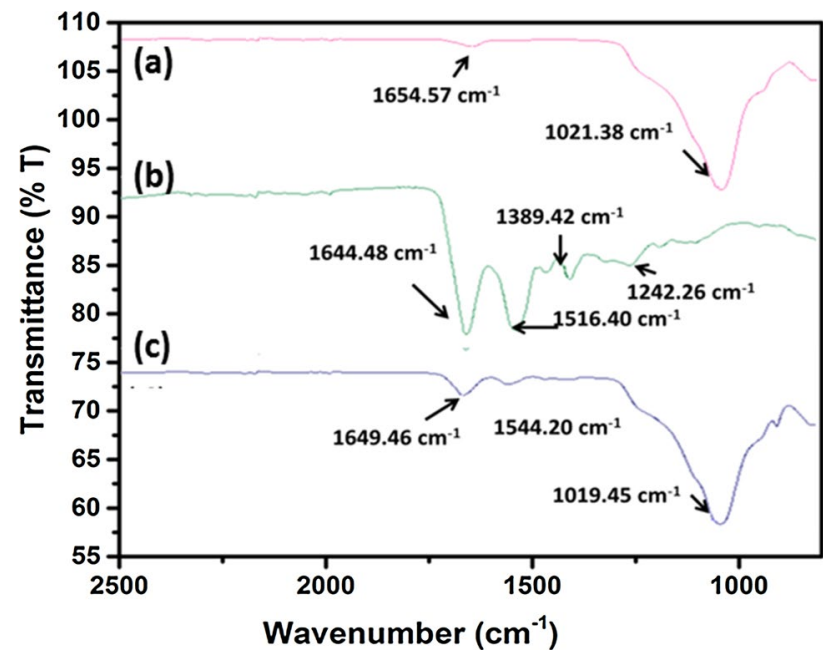

Fig. 5 FTIR spectra of DC (a), BSA (b) and BSA adsorbed DC (c) after $120 \mathrm{~min}$

in the amount of adsorption. The addition of sodium phosphate in the adsorption process causes two influences. In the first case, the amount of salt added to solution medium decreases the interaction by entering between diatomite clay and protein molecules. In the latter case, the surface contact area between diatomite clay and protein molecules increases with the increase in phosphate salt. It can be said that the increase in the adsorption capacity of the adsorption process of these two processes in the second case is a more dominant effect. The similar results are observed in adsorption of biomolecules and dyestuffs on the clay surface (Demirbas 2006; Tekin et al. 2005; Vermöhlen et al. 2000; Vecchia et al. 2005). As shown in Fig. 5, in the adsorption of BSA molecules, temperature effect can be used as an important function. Adsorption experiments were performed to determine the effect of temperature $(288,298,309.5$ and $318 \mathrm{~K})$ on the specific $\mathrm{pH}$, concentration and at all times. The adsorption of protein on the surface of diatomite clay is increased by the increase in the temperature. However, maximum adsorption yield was obtained at a temperature of 36.5 . The protein molecules are very sensitive to temperature. Its structure begins to deteriorate at very high temperatures. The adsorbing zones lose their activity at high temperatures. Therefore, interaction of BSA molecules with support materials is insufficient at very high temperatures which leads to a reduction in the adsorption effect. It shows that the adsorption does not occur chemically but physically. In addition, the increase in adsorption with temperature may decrease the pores of the support material, which may affect support material adsorption capacity (Pronk et al. 1988). It was determined that the increase in temperature caused a serious increase in the amount of adsorption (Bhattacharya et al. 2008; Sariri and Tighe 1996). The protein molecules are usually very active in the temperature range of $35.5-37{ }^{\circ} \mathrm{C}$. The data obtained from the experimental data confirm these expressions. In parallel with his work, Vecchia et al. found that the maximum adsorption of the immobilized lipase enzyme with different support materials was found to be $37^{\circ} \mathrm{C}$ (Vermöhlen et al. 2000). The optimum conditions for enzyme immobilization are obtained at these near temperature values (Vecchia et al. 2005). Sharma 2001 and Xu et al. various investigators have reported an optimal temperature for the lipase enzyme of $37^{\circ} \mathrm{C}$ (Sharma 2001; Xu et al. 1995).

\section{FTIR, SEM images and thermogravimetric (TG-DTA) analyses}

As indicated in Fig. 4a-c, thermogravimetric analysis (TGA) of DC, BSA and BSA adsorbed on DC was performed. Figure $4 \mathrm{a}-\mathrm{c}$ deduces the following results from the TGA curves. For Fig. 4a; when the temperature is increased from 25 to $105{ }^{\circ} \mathrm{C}$, the weight loss of water in clay structure was impregnated with $6.8 \%$ for Fig. $4 \mathrm{a}, 9.6 \%$ for BSA Fig. $4 \mathrm{~b}$ and $6.1 \%$ for BSA adsorbed DC Fig. 4c. As indicated in Fig. 4a, the temperature range of the dehydration event falls at $105-400{ }^{\circ} \mathrm{C}$ which falls due to the release of water in the intermediate layers at this temperature range. The rapid weight loss $(4.5 \%)$ in the temperature range from 400 to $550{ }^{\circ} \mathrm{C}$ is striking with the steep slope of the TGA curve. This can be explained by the dehydroxylation of the sample. As can be seen from the curves of Fig. 4b, c, for SBA and for BSA adsorbent DC, there are two weight loss stages at temperatures of $25-100{ }^{\circ} \mathrm{C}$ and $250-450{ }^{\circ} \mathrm{C}$, respectively. The first stage can be explained by the loss of water, the second stage can be attributed to the dissociation of BSA. Therefore, comparing the TGA scan of BSA adsorbed on DC and DC, extra weight loss of BSA adsorbed on DC can be explained by the deterioration of BSA structure. The 
results of the FTIR spectra of the samples used in the study (Fig. 4a-c) can be explained as follows. As indicated in Fig. 5a, for diatomite, the band at $\sim 1634 \mathrm{~cm}^{-1}$ is caused by $\mathrm{OH}$ bending vibrations of water adsorbed in silicate minerals. The $\sim 1021 \mathrm{~cm}^{-1}$ band originated from the $\mathrm{Si}-\mathrm{O}-\mathrm{Si}$ vibration. In the $\sim 794 \mathrm{~cm}^{-1}$ band, it caused an $\mathrm{OH}$ translational vibration (Montero et al. 1993). FTIR-ATR spectrum analysis of BSA molecule adsorbed on diatomite clay was performed. Unlike the pure diatomite clay structure, the peak in the amide II $\left(\sim 1544 \mathrm{~cm}^{-1}\right)$ band was observed. Amid II band is due to the $\mathrm{N}-\mathrm{H}$ bend at the peptide bond. In this range band, a similar phenomenon has been observed as a result of the adsorption of some biomolecules on the clay (Ilia et al. 2009; Lu et al. 1994).

\section{Kinetic analysis}

The adsorption kinetics between BSA and diatomite clay, which is an oxide mineral, is well defined by the so-called second-order and in-particle diffusion model (Montero et al. 1993). This can be explained by the fact that the clay mineral, an oxide mineral, is more exposed to the interaction of BSA molecules along the open surface area and in the support material with increasing temperature. The kinetic analyzes at adsorption processes were performed at $298 \mathrm{~K}$ and $\mathrm{pH}$ 7. The adsorption is particularly rapid at the beginning (contact time $<30 \mathrm{~min}$ ) and then slows down. The surface area for adsorption at the initial stage of the reaction may be smaller and then, the remaining surface areas affect the adversely propulsive forces between the BSA molecules on the surfaces of the support material bulk phase (Ilia et al. 2009). First, second and intraparticle diffusion models have been tried to determine which model-compatible phenomena of the adsorption phenomenon using experimental data and we can understand which model of adsorption process is being carried out. Equation (4.5) gives equations of equality in the first and second degrees, where qe is the equilibrium value of the adsorption value between diatomite clay and BSA. The $q_{\mathrm{t}}$ is the value of the adsorption of bovine serum albumin and diatomite clay, which is an oxide mineral, at a given time $(\mathrm{mg} / \mathrm{g})$ and $k_{1}$ represents the constant coefficient value from the so-called first-order equation at Eq. (2) (Lu et al. 1994). To understand the kinetic mechanism of the rate of the adsorption process, the pseudo-second-order equation is expressed by Eq. (3) (Giacmelli et al. 1999), where $q_{\mathrm{e}}$ and $k_{2}$ values are obtained from the slope of the linear line of $T / q$ relative to $t$. Furthermore, Eq.(4). is used to obtain the initial adsorption rate of the experimental process.

$\ln \left(q_{\mathrm{e}}-q_{\mathrm{t}}\right)=\ln q_{\mathrm{e}}-k_{i} t$

$\frac{t}{q e}=\frac{1}{k_{2} q_{e}^{2}}+\frac{1}{q_{e}} t$ $h=k_{2} q_{\mathrm{e}}$

$q_{\mathrm{t}}=k_{\text {int. }} t_{1 / 2}+C$

$k_{\text {int }}$ values are obtained from the slope of the linear line of $q_{\mathrm{t}}$ relative to $t_{1 / 2}$ (Li et al. 2006). Table 3 presents the coefficients of the pseudo-first and second-order adsorption kinetic models and the intraparticle diffusion model at $\mathrm{pH}$ 5.5, 7 and 9, respectively. By looking at the $\mathrm{R}^{2}$ coefficient values, it was investigated which model was suitable. Therefore, this study suggests that the second-order-model represents better the adsorption kinetics. The parallel studies have been observed in adsorption studies (Li et al. 2006; Mall et al. 2006). These studies also show that thermodynamic analysis studies give us an idea of whether the adsorption process is physical or chemical. The various mechanisms such as external diffusion, boundary layer diffusion and intraparticle diffusion limit the adsorption kinetic mechanism (El-Naggar et al. 2012). For this reason, the intraparticle diffusion model provides information on the rate-limiting limit of the adsorption process as shown in Fig. 6. If the intraparticle diffusion occurs in a single step of limiting the velocity, then $t_{1 / 2}$ against $\mathrm{Q}$ regression is linear and passes through origin (Ho and McKay 1999). Regression can be linear if the plot does not pass directly through the origin, suggesting that adsorption process involved intraparticle diffusion, but this means that the adsorption mechanism is not the only control step. In which case the adsorption rate controls the other kinetic model, the finding of which is similar to that made in previous works on adsorption $(\mathrm{Li}$ et al. 2006; Mall et al. 2006; El-Naggar et al. 2012; Ho and McKay 1999). The $k_{\text {int }}$ values increased with the temperature (288-318 K), as a result of enhancing the mobility of BSA molecules in the adsorption process. In addition, the value of $C$, like $k_{\text {int }}$ values varied with temperature (Table 4). Determination of the boundary thickness can be understood by $C$ value. The magnitude of a boundary layer diffusion effect is proportional to the magnitude of the corresponding value of $C$ (Ozcan et al. 2006). The results of this study show that the temperature factor is influenced by diffusion boundary layer diffusion (Chiou et al. 2004).

\section{Thermodynamic parameters}

The values of $k_{2}$ are used to the finding of $E_{\mathrm{a}}$ (activation energy) from Arrhenius Eq. (6). In this equation, $A$ is the factor of Arrhenius equation $\left(\mathrm{g} \mathrm{mol}^{-1} \mathrm{~s}^{-1}\right), E_{\mathrm{a}}$ is activation energy $\left(\mathrm{J} \mathrm{mol}^{-1}\right), T$ is the temperature of the solution $(\mathrm{K}), R$ is the constant of gas $\left(\mathrm{J} \mathrm{K}^{-1} \mathrm{~mol}^{-1}\right)$. The activation energy was calculated from the slope of equation as $15.41 \mathrm{~kJ} \mathrm{~mol}^{-1}$. Low activation energies $(5-40 \mathrm{~kJ} / \mathrm{mol})$ indicate that the process is physical and that higher activation energies 


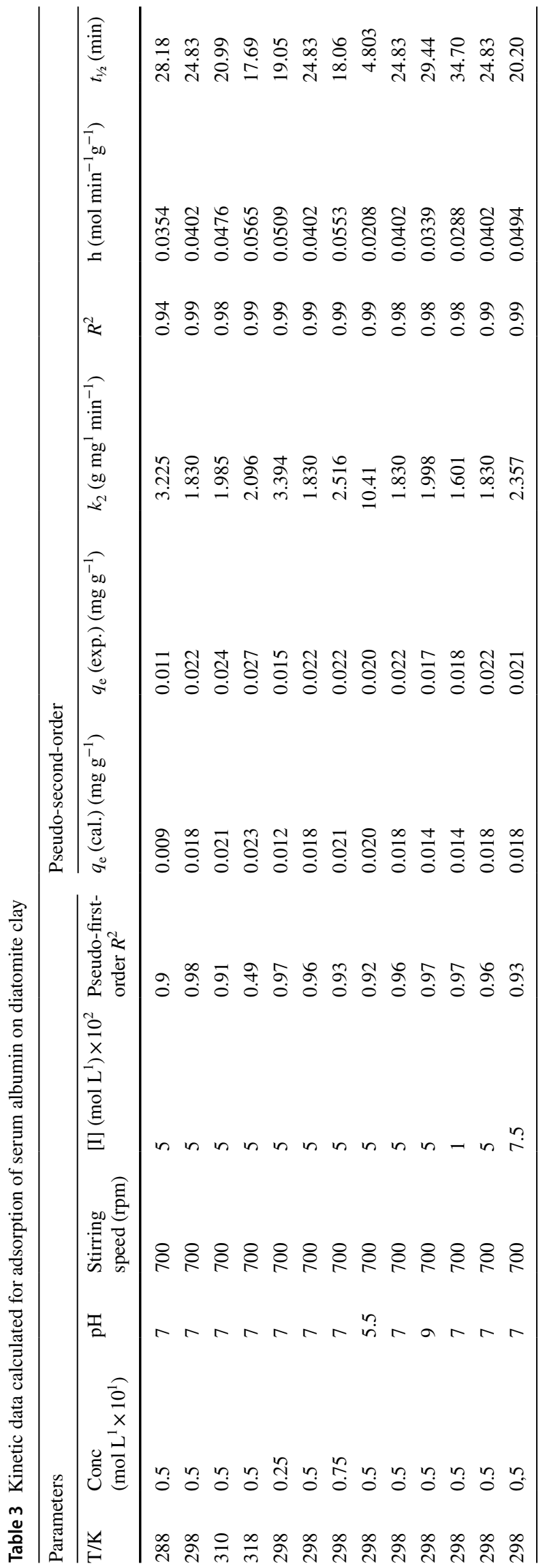

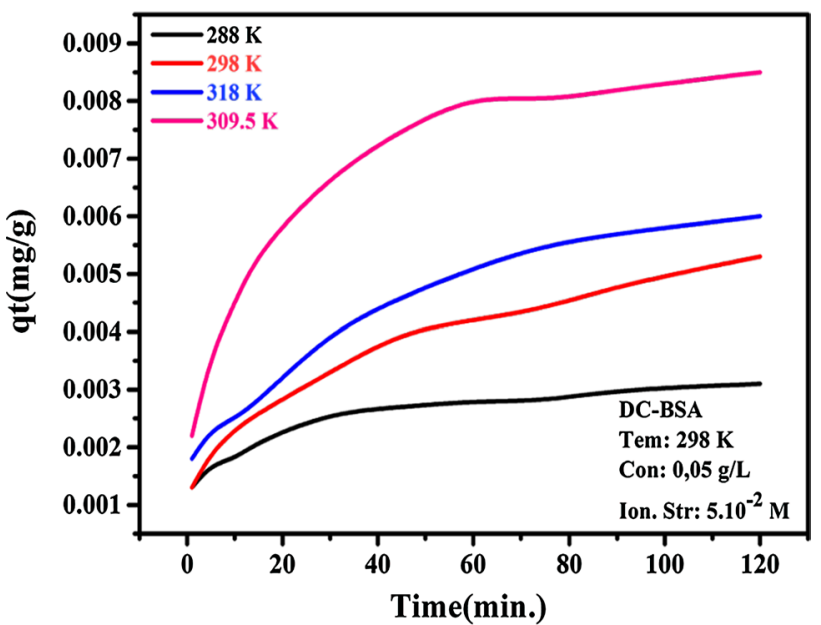

Fig. 6 Intraparticle diffusion plots for different $\mathrm{pH}$

(40-800 kJ / mol) are chemisorption (Guibal et al. 2003). For this reason, the thermodynamic activation parameters of the process such as free energy $\Delta g$, enthalpy $\Delta H$ and entropy $\Delta S$ were determined using the Eyring equation as shown in Fig. 7 (7) (Kannan and Sundaram 2001; Ho et al. 2002; Mall and Upadhyay 1995; Laidler and Meiser 1999).

$\ln k_{2}=\ln A-\frac{E_{\mathrm{a}}}{\operatorname{Rg} \cdot T}$

$\ln \left(k_{2} / T\right)=n(k b / h)+\frac{\Delta S}{R g}-\frac{\Delta H}{R g T}$

In the Eyring Eq. (7), $T$ is the temperature of the solution, $k_{2}$ is constant of rate sorption, $\Delta S$ is entropy, $\Delta$ is enthalpy, $R$ is constant of gas, $k_{\mathrm{b}}$ is the constant of Boltzmann $\left(1.3807 \times 10^{-23} \mathrm{JK}^{-1}\right)$ and $\mathrm{h}$ is the constant of Planck $\left(6.6261 \times 10^{-34} \mathrm{Js}\right)$. The calculated thermodynamic parameters are given in Table 5. The value of $\Delta S$ (entropy change) was founded as $-183.28 \mathrm{~J} \mathrm{~K} \mathrm{~mol}^{-1}$. This value indicates that the serum albumin was distributed regularly on the diatomite clay. The value of $E_{\mathrm{a}}$ is less than $40 \mathrm{~kJ}$, indicating that the adsorption serum albumin on the diatomite clay is physical. The values of $\Delta G$ were found as negative. These values indicate that the adsorption process occurs spontaneously.

\section{Conclusions}

The diatomite clay mineral is very important for the adsorption of BSA molecules because of its low cost, high selectivity, high retention capacity and non-toxicity, and clay mineral can be used as a good adsorbent to retain proteins found in milk industry by-products. The diatomite clay as 
Table 4 Kinetic data calculated for adsorption of lipase enzyme on diatomite clay

Mechanism of adsorption

\begin{tabular}{|c|c|c|c|c|c|c|c|c|c|}
\hline \multicolumn{5}{|l|}{ Mass transfer } & \multicolumn{5}{|c|}{ Intraparticle diffusion } \\
\hline Parameters $(\mathrm{T} / \mathrm{K})$ & $\begin{array}{l}\text { Conc. (mol } \\
\left.\mathrm{L}^{-1}\right) \times 10^{2}\end{array}$ & $\mathrm{pH}$ & $\begin{array}{l}\text { Stirring } \\
\text { speed (rpm) }\end{array}$ & {$[\mathrm{I}]\left(\mathrm{mol} \mathrm{L}^{1}\right) \times 10^{2}$} & $\overline{R^{2}}$ & $\begin{array}{l}k_{\text {int } 1} \\
\left(\mathrm{mg} \mathrm{g}^{-1} \min ^{-1 / 2}\right)\end{array}$ & $R_{1}^{2}$ & $\begin{array}{l}k_{\text {int, } 2} \\
\left(\mathrm{mg} \mathrm{g}^{-1} \min ^{-1}\right)\end{array}$ & $R_{2}^{2}$ \\
\hline 288 & 0.5 & 7 & 700 & 5 & 0.79 & 0.997 & 0.98 & 0.162 & 0.81 \\
\hline 298 & 0.5 & 7 & 700 & 5 & 0.68 & 2.005 & 0.99 & 0.038 & 0.59 \\
\hline 309,5 & 0.5 & 7 & 700 & 5 & 0.77 & 1.968 & 0.99 & 0.802 & 0.77 \\
\hline 318 & 0.5 & 7 & 700 & 5 & 0.76 & 2.725 & 0.99 & 0.601 & 0.77 \\
\hline 298 & 0.5 & 7 & 700 & 5 & 0.73 & 1.374 & 0.99 & 0.154 & 0.59 \\
\hline 298 & 0.25 & 7 & 700 & 5 & 0.68 & 2.005 & 0.99 & 0.038 & 0.59 \\
\hline 298 & 0.5 & 7 & 700 & 5 & 0.79 & 1.833 & 0.99 & 0.401 & 0.77 \\
\hline 298 & 0.75 & 5.5 & 700 & 5 & 0.54 & 1.844 & 0.99 & 0.038 & 0.59 \\
\hline 298 & 0.5 & 7 & 700 & 5 & 0.68 & 2.005 & 0.99 & 0.038 & 0.59 \\
\hline 298 & 0.5 & 9 & 700 & 5 & 0.77 & 1.207 & 0.98 & 0.186 & 0.87 \\
\hline 298 & 0.5 & 7 & 700 & 1 & 0.67 & 1.754 & 0.99 & 0.131 & 0.99 \\
\hline 298 & 0.5 & 7 & 700 & 5 & 0.68 & 2.005 & 0.99 & 0.038 & 0.59 \\
\hline 298 & 0.5 & 7 & 700 & 7.5 & 0.7 & 2.257 & 0.97 & 0.225 & 0.73 \\
\hline
\end{tabular}

(a)

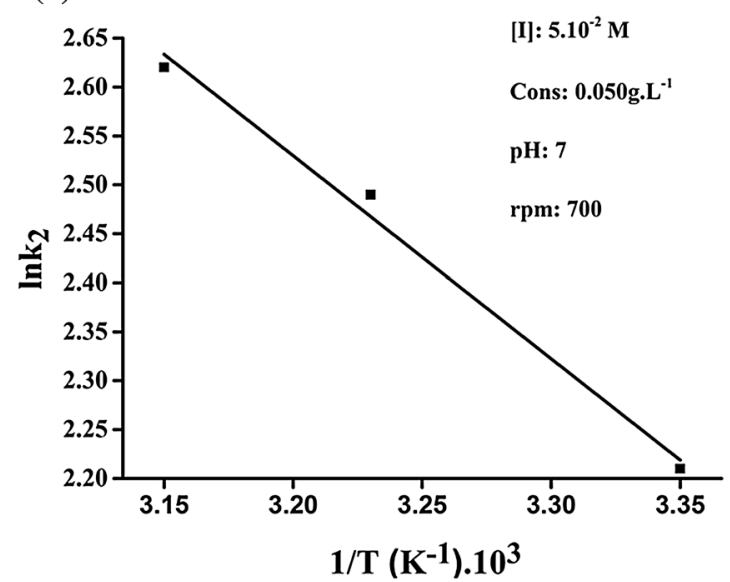

(b)

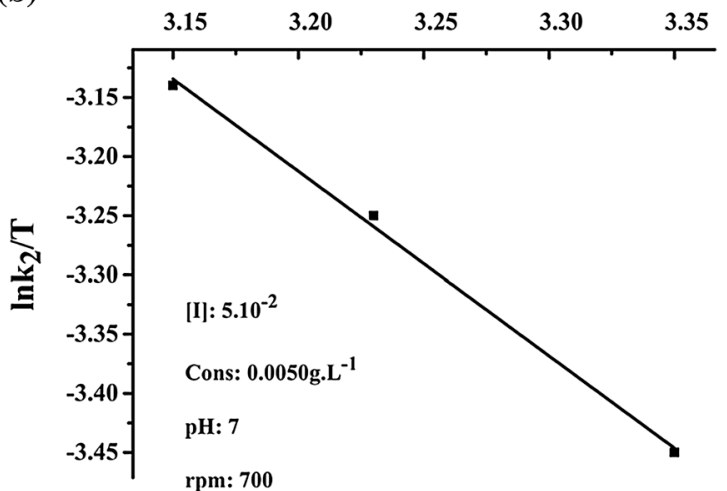

Fig. 7 Arrhenius plot and thermodynamic function for the adsorption of BSA on diatomite clay

Table 5 Thermodynamic function data obtained by adsorption of BSA on diatomite clay surface

$\begin{array}{lllll}\text { Parameters } & \Delta G(\mathrm{~kJ} / \mathrm{mol}) & E_{\mathrm{a}}(\mathrm{kJ} / \mathrm{mol}) & \Delta H(\mathrm{~kJ} / \mathrm{mol}) & \Delta S(\mathrm{~J} / \mathrm{K} \mathrm{mol})\end{array}$ $(\mathrm{T} / \mathrm{K})$

\begin{tabular}{lllll}
\hline 288 & -65.62 & 15.41 & -12.8409 & -183.28 \\
298 & -67.45 & & & \\
309.5 & -69.56 & & & \\
318 & -71.12 & & & \\
\hline
\end{tabular}

support material in adsorption processes is strong effective for adsorbing BSA molecules from aqueous media. The data obtained in the adsorption process are specifically dependent on the initial BSA concentration, duration of contact, $\mathrm{pH}$ and the temperature. It was clearly seen that the amount of adsorption increased proportionally with increasing contact time and becomes gradual after $30 \mathrm{~min}$. The BSA adsorption amount adsorbed by the diatomite clay had a maximum value at a $\mathrm{pH}$ of 5.5 and decreases with increasing the solution $\mathrm{pH}$. The amount of adsorption increased with increasing BSA molecule concentration and as indicated in Fig. 5, the highest adsorption takes place at $309.5 \mathrm{~K}$. Also, the diatomite clay mineral is very important for the adsorption of BSA molecules because of its low cost, high selectivity, high retention capacity and non-toxicity, and clay mineral can be used as a good adsorbent to retain proteins found in milk industry by-products. The adsorption of serum albumin on 
diatomite clay was investigated. Herein, values of free Gibbs energy were found as negative. The negative value of the Gibbs energy change of the adsorption indicates that the adsorption is spontaneous. This indicates that the adsorption event takes place without the need for an outside energy. The process of the adsorption of the diatomite clay was found to be physical due to the value of activated energy. According to the value entropy, the process has occurred regularly on the diatomite clay. Value of enthalpy was found as $-12.84 \mathrm{~kJ} \mathrm{~mol}^{-1}$. This value indicates that the process of adsorption lipase enzyme on diatomite clay is exothermic. The adsorption process increased with increasing of initial concentration of the BSA, ionic strength and increasing contact time. The diatomite clay has a high potential to adsorb these BSA from aqueous solutions. Therefore, it can be effectively used as an adsorbent for the adsorption of BSA. The additional work on this area leads to the development of support materials for recovery of existing biomolecules from food industry wastes.

Open Access This article is distributed under the terms of the Creative Commons Attribution 4.0 International License (http://creativeco mmons.org/licenses/by/4.0/), which permits unrestricted use, distribution, and reproduction in any medium, provided you give appropriate credit to the original author(s) and the source, provide a link to the Creative Commons license, and indicate if changes were made.

\section{References}

Abrahamson JT, Sen F, Sempere B, Wal MP (2013) Excess thermopower and the theory of thermopower waves. ACS Nano 7(8):6533-6544

Aday B, Yildiz Y, Ulus R et al (2016a) One-pot, efficient and green synthesis of acridinedione derivatives using highly monodisperse platinum nanoparticles supported with reduced graphene oxide. New J Chem 40:748-754

Aday B, Pamuk H, Kaya M, Sen F (2016b) Graphene oxide as highly effective and readily recyclable catalyst using for the one-pot synthesis of 1,8-dioxoacridine derivatives. J Nanosci Nanotechnol 16:6498-6504

Ahmaruzzaman M, Gupta VK (2011) Rice husk and its ash as low-cost adsorbents in water and wastewater treatment. Ind Eng Chem Res 50(24):13589-13613

Akkuş P (2006) Sugar Esters Synthesis Using Lipase. G.Y.T.E. Institute of Engineering and Science, Istanbul

Akocak S, Sen B, Lolak N et al (2017) One-pot three-component synthesis of 2-Amino-4H-chromene derivatives by using monodisperse Pd nanomaterials anchored graphene oxide as highly efficient and recyclable catalyst. Nano Struct Nano Objects $11: 25-31$

Asfaram A, Ghaedi M, Agarwal S, Tyagib I, Gupta VK (2015) Removal of basic dye Auramine-O by ZnS: cu nanoparticles loaded on activated carbon: optimization of parameters using response surface methodology with central composite design. RSC Adv 5:18438-18450

Ayranci R, Baskaya G, Guzel M et al (2017a) Carbon-based nanomaterials for high-performance optoelectrochemical systems. Chem Select 2(4):1548-1555
Ayranci R, Baskaya G, Guzel M et al (2017b) Enhanced optical and electrical properties of PEDOT via nanostructured carbon materials: a comparative investigation. Nano Struct Nano Objects 11:13-19

Baskaya G, Yıldız Y, Savk A et al (2017a) Rapid, sensitive, and reusable detection of glucose by highly monodisperse nickel nanoparticles decorated functionalized multi-walled carbon nanotubes. Biosens Bioelectron 91:728-733

Baskaya G, Esirden I, Erken E et al (2017b) Synthesis of 5-substituted-1H-tetrazole derivatives using monodisperse carbon black decorated pt nanoparticles as heterogeneous nanocatalysts. J Nanosci Nanotechnol 17:1992-1999

Bhattacharya AK, Naiya TK, Mandal SN, Das SK (2008) Adsorption, kinetics and equilibrium studies on removal of $\mathrm{Cr}(\mathrm{VI})$ from aqueous solutions using different low-cost adsorbents. J Chem Eng 137:529-541

Bozkurt S, Tosun B, Sen B et al (2017) A hydrogen peroxide sensor based on TNM functionalized reduced graphene oxide grafted with highly monodisperse Pd nanoparticles. Anal Chim Acta 989C: 88-94

Brandes N, Welzel PB, Werner C, Kroh LW (2006) Adsorptioninduced Confor5mational changes of proteins onto ceramic particles: differential scanning calorimetry and FTIR analysis. J Colloid Interface Sci 299:56-69

Celik B, Baskaya G, Karatepe O et al (2016a) Monodisperse Pt(0)/ DPA@GO nanoparticles as highly active catalysts for alcohol oxidation and dehydrogenation of DMAB. Int J Hydrogen Energy 41:5661-5669

Celik B, Yildiz Y, Erken E et al (2016b) Monodisperse Palladiumcobalt alloy nanoparticles assembled on poly ( $N$-vinyl-pyrrolidone) (PVP) as highly effective catalyst for the dimethylamine borane (DMAB) dehydrocoupling. RSC Adv 6:24097-24102

Celik B, Erken E, Eris S et al (2016c) Highly monodisperse Pt(0)@ AC NPs as highly efficient and reusable catalysts: the effect of the surfactant on their catalytic activities in room temperature dehydrocoupling of DMAB. Catal Sci Technol 6:1685-1692

Celik B, Kuzu S, Erken E et al (2016d) Nearly monodisperse carbon nanotube furnished nanocatalysts as highly efficient and reusable catalyst for dehydrocoupling of DMAB and C1-C3 Alcohol Oxidation. Int J Hydrogen Energy 41:3093-3101

Chiou MS, Ho PY, Li HY (2004) Adsorption of anionic dyes in acid solutions using chemically cross-linked chitosan beads. Dyes Pigm 60:69-84

Dasdelen Z, Y1ldiz Y, Eris S et al (2017) Enhanced electrocatalytic activity and durability of $\mathrm{Pt}$ nanoparticles decorated with GOPVP hybrid material for methanol oxidation reaction. Appl Catal B 219C:511-516

Demir E, Savk A, Sen B et al (2017a) A novel monodisperse metal nanoparticles anchored graphene oxide as counter electrode for dye-sensitized solar cells. Nano-Struct Nano-Objects 12:41-45

Demir E, Sen B, Sen F (2017b) Highly efficient nanoparticles and f-MWCNT nanocomposites based counter electrodes for dyesensitized solar cells. Nano Struct Nano Objects 11:39-45

Demirbas Ö (2006) Doctoral Thesis, Balikesir University Institute of Science, Balikesir

Demirci T, Celik B, Yıldız Y (2016) One-pot synthesis of hantzsch dihydropyridines using highly efficient and stable PdRuNi@ GO catalyst. RSC Adv 6:76948-76956

Devaraj M, Saravanan R, Deivasigamani RK, Gupta VK, Gracia F, Jayadevan $\mathrm{S}$ (2016) Fabrication of novel shape $\mathrm{Cu}$ and $\mathrm{Cu}$ / $\mathrm{Cu}_{2} \mathrm{O}$ nanoparticles modified electrode for the determination of dopamine and paracetamol. J Mol Liq 221:930-941

Doğan M, Alkan M, Demirbaş Ö, Özdemir Y, Özmetin C (2006) Adsorption kinetics of Maxilon Blue GRL onto sepiolite from aqueous solutions. Chem Eng J 124:89-101

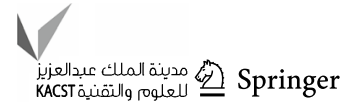


El-Naggar IM, Zakaria ES, Ali IM, Khalil M, El-Shahat MF (2012) Kinetic modeling analysis for the removal of cesium ions from aqueous solutions using polyaniline titanotungstate. Arab J Chem 5:109-119

Eris S, Dasdelen Z, Sen F (2018a) Enhanced electrocatalytic activity and stability of monodisperse Pt nanocomposites for direct methanol fuel cells. J Colloid Interface Sci 513:767-773

Eris S, Dasdelen Z, Yildiz Y et al (2018b) Nanostructured Polyaniline-rGO decorated platinum catalyst with enhanced activity and durability for Methanol oxidation. Int J Hydrogen Energy 43(3):1337-1343

Eris S, Dasdelen Z, Sen F et al (2018c) Investigation of electrocatalytic activity and stability of Pt@f-VC catalyst prepared by in situ synthesis for methanol electrooxidation. Int J Hydrogen Energy 43(1):385-390

Erkan A, Bakir U, Karakas G (2006) Photocatalytic microbial inactivation over $\mathrm{Pd}$ doped $\mathrm{SnO}_{2}$ and $\mathrm{TiO}_{2}$ thin films. J Photochem Photobiol A 184(3):313-321

Erken E, Esirden I, Kaya M et al (2015) A rapid and novel method for the synthesis of 5 -substituted $1 \mathrm{H}$-tetrazole catalyzed by exceptional reusable monodisperse Pt NPs@AC under the microwave irradiation. RSC Adv 5:68558-68564

Erken E, Pamuk H, Karatepe O et al (2016a) New Pt(0) nanoparticles as highly active and reusable catalysts in the $\mathrm{C} 1-\mathrm{C} 3$ alcohol oxidation and the room temperature dehydrocoupling of dimethylamine-borane (DMAB). J Cluster Sci 27:29

Erken E, Yildiz Y, Kilbas B et al (2016b) Synthesis and characterization of nearly monodisperse Pt nanoparticles for C1-C3 Alcohol Oxidation and Dehydrogenation of dimethylamine-borane (DMAB). J Nanosci Nanotechnol 16:5944-5950

Esirden I, Erken E, Kaya M et al (2015) Monodisperse Pt NPs@ rGO as highly efficient and reusable heterogeneous catalysts for the synthesis of 5-substituted $1 \mathrm{H}$-tetrazole derivatives. Catal Sci Technol 5:4452-4457

Gezer B, Onal Okyay T, Bozkurt S, Baskaya G, Sahin B, Uluturk C, Sen F (2017) Reduced graphene oxide (rGO) as Highly effective material for the ultrasound-assisted boric acid extraction from ulexite ore. Chem Eng Res Des 117C:542-548

Ghaedi M, Hajjati S, Mahmudi Z, Tyagi I, Agarwal S, Maity A, Gupta VK (2015) Modeling of competitive ultrasonic assisted removal of the dyes-methylene blue and Safranin-O using $\mathrm{Fe}_{3} \mathrm{O}_{4}$ nanoparticles. Chem Eng J 268:28-37

Giacmelli CE, Bremer MG, Norde WJ (1999) ATR-FTIR study of $\mathrm{IgG}$ adsorbed on different silica surfaces. Colloid Interface Sci. 220:13-23

Giacomelli CE, Norde W (2001) The adsorption-desorption cycle reversibility of the BSA-silica system. J Colloid Interface Sci 233:234-240

Giraldo JP, Landry MP, Fal SM (2014) A nanobionic approach to augment plant photosynthesis and biochemical sensing using targeted nanoparticles. Nat Mater 13:400-408

Goksu H, Celik B, Yildiz Y et al (2016a) Superior monodisperse CNTSupported CoPd (CoPd@CNT) nanoparticles for selective reduction of nitro compounds to primary amines with $\mathrm{NaBH}_{4}$ in the aqueous medium. Chem Select 1(10):2366-2372

Goksu H, Yildiz Y, Celik B et al (2016b) Highly efficient and monodisperse graphene oxide furnished Ru/Pd Nanoparticles for the dehalogenation of aryl halides via ammonia borane. Chem Select 1(5):953-958

Goksu H, Yildiz Y, Celik B et al (2016c) Eco-friendly hydrogenation of aromatic aldehyde compounds by tandem dehydrogenation of dimethylamine-borane in the presence of reduced graphene oxide furnished platinum nanocatalyst. Catal Sci Technol 6:2318-2324
Goksu H, Kilbas B, Sen F (2017) Recent advance in the reduction of nitro compounds by heterogenous catalysts. Curr Org Chem 21(9):794-820

Guibal E, McCarrick P, Tobin JM (2003) Comparison of the sorption of anionic dyes on activated carbon and chitosan derivatives from dilute solutions. Sep Sci Technol 38:3049-3073

Gupta VK, Saleh TA (2013) Sorption of pollutants by porous carbon, carbon nanotubes and fullerene-an overview. Environ Sci Pollut Res 20(5):2828-2843

Gupta VK, Jain R, Nayak A, Agarwal S, Shrivastava M (2011) Removal of the hazardous dye-tartrazine by photodegradation on titanium dioxide surface. Mater Sci Eng C 31(5):1062-1067

Gupta VK, Nayak A, Agarwal S, Tyagi I (2014a) Potential of activated carbon from waste rubber tire for the adsorption of phenolics: Effect of pre-treatment conditions. J Colloid Interface Sci 417:420-430

Gupta VK, Atar N, Yola ML, Ustundag Z, Uzun L (2014b) A novel magnetic Fe@Au core-shell nanoparticles anchored graphene oxide recyclable nanocatalyst for the reduction of nitrophenol compounds. Water Res 48:210-217

Gupta VK, Nayak A, Agarwal S (2015) Bioadsorbents for remediation of heavy metals: current status and their future prospects. Environ Eng Res 20:001-018

Ho YS, McKay G (1999) Pseudo-second order model for sorption processes. Process Biochem 34(451):465

Ho YS, Porter JF, Mckay G (2002) Equilibrium isotherm studies for the sorption of divalent metal ions onto peat: copper, nickel and lead single component systems. Water Air Soil Pollut $141: 1-33$

$\mathrm{Hu}$ T, Su Z (2003) A solid phase adsorption method for preparation of bovine serum albumin bovine hemoglobin conjugate. J Biotechnol 100:267-275

Huang BX, Kim HY (2004) Probing three-dimensional structure of Bovine serum albumin by chemical cross-linking and mass spectrometry. J Am Soc Mass Spectrom 15:1237-1247

Hunter J (1999) Introduction to modern colloid science. Oxford University Press, New York

Ilia IK, Stamatakis MG, Perraki TS (2009) Mineralogy and technical properties of clayey diatomites from the north and Central Greece. Cent Eur J Geosci 1:393-403

Iverson NM, Barone PW, Sen F, Shandell M et al (2013) vivo biosensing via tissue-localizable near- infrared-fluorescent single-walled carbon nanotubes. Nat Nanotechnol 8(11):873-880

Kannan K, Sundaram MM (2001) Kinetics and mechanism of removal of Methylene Blue by adsorption on various carbons a comparative study. Dyes Pigm 51:25-40

Karatepe O, Yildiz Y, Pamuk H et al (2016) Enhanced electrocatalytic activity and durability of highly monodisperse Pt@PPy-PANI nanocomposites as a novel catalyst for electro-oxidation of methanol. RSC Adv 6:50851-50857

Khani H, Rofouei MK, Arab P, Gupta VK, Vafaei Z (2010) Multiwalled carbon nanotubes-ionic liquid-carbon paste electrode as a super selectivity sensor: application to potentiometric monitoring of mercury ion(II). J Hazard Mater 183(1-3):402-409

Khraisheh MAM, Al-degs YS, Mcminn WAM (2004) Remediation of wastewater containing heavy metals using raw and modified diatomite. Chem Eng J 99:177-184

Koskun Y, Savk A, Sen B, Sen F (2018) Highly sensitive glucose sensor based on monodisperse Palladium Nickel/activated carbon nanocomposites. Anal Chim Acta 1010:37-43

Kudelski A (2003) Influence of electrostatically bound proteins on the structure of linkage monolayers: adsorption of bovine serum albumin on silver and gold substrates coated with monolayers of 2-mercaptoethanesulphonate. Vib Spectrosc 33:197-204

Laidler KJ, Meiser JM (1999) Physical chemistry. Houghton Mifflin, New York, p 852 
Lemonas JF (1997) Diatomite. Am Ceram Soc Bull 76:92-95

Li YH, Zhu Y, Zhao Y, Wu D, Luan Z (2006) Different morphologies of carbon nanotubes effect on the lead removal from aqueous solution. Diamond Relat Mater 15:90-94

Lu CF, Nadarajah A, Chittur KK (1994) A comprehensive model for protein adsorption to surfaces. J Colloid Interface Sci 168:152-161

Mall ID, Upadhyay SN (1995) Treatment of methyl violet bearing wastewater from paper mill effluent using low-cost adsorbents. J Indian Pulp Paper Technol Assoc 7(1):51-57

Mall ID, Srivastava VC, Agarwal NK (2006) Removal of Orange-G and methyl violet dyes by adsorption on bagasse fly ash kinetic study and equilibrium isotherm analyses. Dyes Pigm 69:210-223

Mansch HH, Chapman D (1996) Infrared spectroscopy of biomolecules. Wiley, New York, pp 239-278

McClellan SJ, Franses EI (2003) Effect of concentration and denaturation on adsorption and surface tension of bovine serum albumin. Colloids Surf B Biointerfaces 28:63-75

Mittal A, Mittal J, Malviya A, Gupta VK (2010) Removal and recovery of Chrysoidine Y from aqueous solutions by waste materials. J Colloid Interface Sci 344(2):497-507

Mohammadi N, Khani H, Gupta VK, Amereh E, Agarwal S (2011) Adsorption process of methyl orange dye onto mesoporous carbon material-kinetic and thermodynamic studies. J Colloid Interface Sci 362(2):457-462

Montero S, Blanco A, Virto M, Ladenta LC, Agud I, Solozabal R, Lascaray JM, Renobales M, Llama MJ, Serra JL (1993) Immobilization of Candida rugosa lipase and some properties of the immobilized enzyme. Enzyme Microb Technol 15:239-247

Norde W, Baszkin A, Norde W (eds) (2000) Physical chemistry of biological interfaces. Marcel Dekker Inc., New York, p 115

Ozcan A, Oncu EM, Ozcan AS (2006) Kinetics isotherm and thermodynamic studies of adsorption of Acid Blue 193 from aqueous solutions on natural sepiolite. Colloid Surf A 277:90-97

Pamuk H, Aday B, Kaya M, Sen F (2015) Pt Nps@GO as highly efficient and reusable catalyst for one-pot synthesis of acridinedione derivatives. RSC Adv 5:49295-49300

Pronk W, Kerkhof PJAM, Van Helden C, Van Riet K (1988) The hydrolysis of triglycerides by immobilized lipase in a hydrophilic membrane reactor. Biotechnol Bioeng 32:512-518

Rigou P, Rezaei H, Grosclaude J, Staunton S, Quiquampoix H (2006) Fate of prions in soil: adsorption and extraction by electroelution of recombinant ovine prion protein from montmorillonite and natural soils. Environ Sci Technol 40:1497-1503

Robati D, Mirza B, Rajabi M, Moradi O, Tyagi I, Agarwale S, Gupta VK (2016) Removal of hazardous dyes-BR 12 and methyl orange using graphene oxide as an adsorbent from aqueous phase. Chem Eng J 284:687-697

Sahin B, Demir E, Aygun A et al (2017) Investigation of the Effect of pomegranate extract and monodisperse silver nanoparticle combination on MCF-7 cell line. J Biotechnol 260C:79-83

Sahin B, Aygun A, Gunduz H et al (2018) cytotoxic effects of platinum nanoparticles obtained from pomegranate extract by the green synthesis method on the MCF-7 cell Line. Colloids Surf B 163:119-124

Saleh TA, Gupta VK (2011) Functionalization of tungsten oxide into MWCNT and its application for sunlight-induced degradation of rhodamine B. J Colloid Interface Sci 362(2):337-344

Saleh TA, Gupta VK (2012a) Photo-catalyzed degradation of hazardous dye methyl orange by use of a composite catalyst consisting of multi-walled carbon nanotubes and titanium dioxide. J Colloid Interface Sci 371(1):101-106

Saleh TA, Gupta VK (2012b) Synthesis and characterization of alumina nano-particles polyamide membrane with enhanced flux rejection performance. Sep Purif Technol 89:245-251
Saleh TA, Gupta VK (2014) Processing methods and characteristics of porous carbons derived from waste rubber tires: a review. Adv Colloid Interface Sci 211:92-100

Saravanan R, Karthikeyan S, Gupta VK, Sekaran G, Narayanan V, Stephen A (2013a) Enhanced photocatalytic activity of $\mathrm{ZnO} / \mathrm{CuO}$ nanocomposite for the degradation of textile dye on visible light illumination. Mater Sci Eng C33(1):91-98

Saravanan R, Thirumal E, Gupta VK, Narayanan V, Stephen A (2013b) The photocatalytic activity of $\mathrm{ZnO}$ prepared by simple thermal decomposition method at various temperatures. J Mol Liq 177:394-401

Saravanan R, Gupta VK, Prakash T, Narayanan V, Stephen A (2013c) Synthesis, characterization and photocatalytic activity of novel $\mathrm{Hg}$ doped $\mathrm{ZnO}$ nanorods prepared by thermal decomposition method. J Mol Liq 178:88-93

Saravanan R, Joicy S, Gupta VK, Narayanan V, Stephen A (2013d) Visible light induced degradation of methylene blue using $\mathrm{CeO}_{2} / \mathrm{V}_{2} \mathrm{O}_{5}$ and $\mathrm{CeO}_{2} / \mathrm{CuO}$ catalysts. Mater Sci Eng C 33(8):4725-4731

Saravanan R, Karthikeyan N, Gupta VK, Thirumal E, Thangadurai P, Narayanan V, Stephen A (2013e) ZnO/Ag nanocomposite: an efficient catalyst for degradation studies of textile effluents under visible light. Mater Sci Eng C 33(4):2235-2244

Saravanan R, Khan MM, Gupta VK, Mosquera E, Gracia F, Narayanan $\mathrm{V}$, Stephen A (2015a) $\mathrm{ZnO} / \mathrm{Ag} / \mathrm{CdO}$ nanocomposite for visible light-induced photocatalytic degradation of industrial textile effluents. J Colloid Interface Sci 452:126-133

Saravanan R, Khan MM, Gupta VK, Mosquera E, Gracia F, Narayanang $\mathrm{V}$, Stephen $\mathrm{A}(2015 \mathrm{~b}) \mathrm{ZnO} / \mathrm{Ag} / \mathrm{Mn}_{2} \mathrm{O}_{3}$ nanocomposite for visible light-induced industrial textile effluent degradation, uric acid and ascorbic acid sensing and antimicrobial activity. RSC Adv 5:34645-34651

Saravanan R, Sacari E, Gracia F, Khan MM, Mosquera E, Gupta VK (2016a) Conducting PANI stimulated $\mathrm{ZnO}$ system for visible light photocatalytic degradation of coloured dyes. J Mol Liq 221:1029-1033

Saravanan R, Khan MM, Gracia F, Qin J, Gupta VK, Arumainathan S (2016b) $\mathrm{Ce}^{3+}$-ion-induced visible-light photocatalytic degradation and electrochemical activity of $\mathrm{ZnO} / \mathrm{CeO}_{2}$ nanocomposite. Sci Rep 6:31641

Sariri R, Tighe B (1996) Effect of surface chemistry on protein interaction with hydrogel contact lenses. J Iran Polym 5:259-266

Sen F, Gokagac G (2007) Different sized platinum nanoparticles supported on carbon: an XPS study on these methanol oxidation catalysts. J Phys Chem C 111:5715-5720

Sen F, Gokagac G (2008) Improving catalytic efficiency in the methanol oxidation reaction by inserting $\mathrm{Ru}$ in face-centered cubic Pt nanoparticles prepared by a new surfactant, tert-octanethiol. Energy Fuels 22(3):1858-1864

Sen F, Gokagac G (2014) Pt nanoparticles synthesized with new surfactants: improvement in $\mathrm{C} 1-\mathrm{C} 3$ alcohol oxidation catalytic activity. J Appl Electrochem 44(1):199-207

Sen F, Gokagac G et al (2007) The activity of carbon supported platinum nanoparticles towards methanol oxidation reaction - the role of the metal precursor and a new surfactant, tert-octanethiol. J Phys Chem C 111:1467-1473

Sen F, Sen S, Gokagac G et al (2011a) Efficiency enhancement in the methanol/ethanol oxidation reactions on Pt nanoparticles prepared by a new surfactant, 1,1-dimethyl heptanethiol, and surface morphology by AFM. Phys Chem Chem Phys 13:1676-1684

Sen S, Sen F, Gokagac G (2011b) Preparation and characterization of nano-sized $\mathrm{Pt}-\mathrm{Ru} / \mathrm{C}$ catalysts and their superior catalytic activities for methanol and ethanol oxidation. Phys Chem Chem Phys 13:6784-6792 
Sen F, Boghossian AA, Sen S et al (2012a) Observation of oscillatory surface reactions of riboflavin, trolox, and singlet oxygen using single carbon nanotube fluorescence spectroscopy. ACS Nano 6(12):10632-10645

Sen F, Ertan S, Sen S et al (2012b) Platinum nanocatalysts prepared with different surfactants for $\mathrm{C} 1-\mathrm{C} 3$ alcohol oxidations and their surface morphologies by AFM. J Nanopart Res 14:922-926

Sen F, Ozturk Z, Sen S et al (2012c) The preparation and characterization of nano-sized Pt-Pd alloy catalysts and comparison of their superior catalytic activities for methanol and ethanol oxidation. J Mater Sci 47:8134-8144

Sen F, Boghossian AA, Sen S et al (2013a) Application of Nanoparticle antioxidants to enable hyperstable chloroplasts for solar energy harvesting. Adv Energy Mater 3(7):881-893

Sen S, Sen F, Boghossian AA et al (2013b) The effect of reductive dithiothreitol and trolox on nitric oxide quenching of single-walled carbon nanotubes. J Phys Chem C 117(1):593-602

Sen F, Sen S, Gokagac G (2013c) High-performance Pt nanoparticles prepared by new surfactants for $\mathrm{C} 1-\mathrm{C} 3$ alcohol oxidation reactions. J Nanopart Res 15:1979

Sen F, Karatas Y, Gülcan M et al (2014a) Amylamine stabilized platinum (0) nanoparticles: active and reusable nanocatalyst in the room temperature dehydrogenation of dimethylamine- borane. RSC Adv 4(4):1526-1531

Sen F, Ulissi ZW, Gong X et al (2014b) Spatiotemporal Intracellular nitric oxide signaling captured using internalized, nearinfrared fluorescent carbon nanotube nanosensors. Nano Lett 14(8):4887-4894

Sen B, Lolak N, Paralı O et al (2017a) Bimetallic PdRu/graphene oxide based catalysts for a one-pot three-component synthesis of 2-amino-4H-chromene derivatives. Nano Struct Nano Objects 12:33-40

Sen B, Kuzu S, Demir E et al (2017b) Hydrogen liberation from the dehydrocoupling of dimethylamine-borane at room temperature by using novel and highly monodispersed RuPtNi nanocatalysts decorated with graphene oxide. Int J Hydrogen Energy 42(36):23299-23306

Sen B, Kuzu S, Demir E et al (2017c) Monodisperse palladiumnickel alloy nanoparticles assembled on graphene oxide with the high catalytic activity and reusability in the dehydrogenation of dimethylamine-borane. Int J Hydrogen Energy 42(36):23276-23283

Sen B, Kuzu S, Demir E et al (2017d) Highly efficient catalytic dehydrogenation of dimethyl ammonia borane via monodisperse Palladium-nickel alloy nanoparticles assembled on PEDOT. Int $\mathbf{J}$ Hydrogen Energy 42(36):23307-23314

Sen B, Kuzu S, Demir E et al (2017e) Highly monodisperse RuCo nanoparticles decorated on functionalized multiwalled carbon nanotube with the highest observed catalytic activity in the dehydrogenation of dimethylamine borane. Int J Hydrogen Energy 42(36):23292-23298

Sen B, Kuzu S, Demir E et al (2017f) Polymer-graphene hybrid decorated Pt nanoparticles as highly efficient and reusable catalyst for the Dehydrogenation of Dimethylamine-borane at room temperature. Int J Hydrogen Energy 42(36):23284-23291

Sen B, Akdere EH, Savk A et al (2018a) A novel thiocarbamide functionalized graphene oxide supported bimetallic monodisperse Rh-Pt nanoparticles (RhPt/TC@ GO NPs) for Knoevenagel condensation of aryl aldehydes together with malononitrile. Appl Catal B 225(5):148-153

Sen B, Savk A, Sen F (2018b) Highly efficient monodisperse nanoparticles confined in the carbon black hybrid material for hydrogen liberation. J Colloid Interface Sci 520:112-118

Sharma YC (2001) Effect of temperature on interfacial adsorption of Cr(VI) on Wollastonite. J Colloid Interface Sci 223:265-270

Sheng GD, Wang SW, Hu J, Lu Y, Li JX, Dong YH, Wang XK (2009) Adsorption of $\mathrm{Pb}(\mathrm{II})$ on diatomite as affected via aqueous solution chemistry and temperature. Colloids Surf A 339:159-166

Tasman W, Ajaeger E (1998) Dane's clinical ophthalmology, vol 4. Lippincott, New York

Tekin N, Demirbaş O, Alkan M (2005) Adsorption of cationic polyacrylamide onto kaolinite. Micropor Mesopor Mater 85:340-350

Topuz O, Saglam BC, Sen F, Sen S, Gokagac G, Gorgul G (2010) Effects of sodium hypochlorite on gutta-percha and resilon cones: an atomic force microscopy and SEM study. Oral Surg Oral Med Oral Pathol Oral Radiol Endod 112(4):21-26

Vecchia RD, Sebrao D, Nascimento MG, Soldı V (2005) Carboxymethylcellulose and poly (vinyl alcohol) used as a film support for lipases immobilization. Process Biochem 40:2677-2682

Vermöhlen K, Lewandowski HD, Narres HD, Schwuger M (2000) Kinetics mechanisms and adsorption of bovine serum albumin on diatomite clay from aqueous solutions. J Colloid Surf A 163:45-53

Violante A, De Cristofaro A, Rao MA, Gianfreda L (1995) Physicochemical properties of protein-smectite and protein- $\mathrm{Al}(\mathrm{OH})$ x-smectite complexes. Clay Miner 30:325-336

Vroman L, Adams AL (1969) Findings with the recording ellipsometer suggesting the rapid exchange of specific plasma proteins at liquid/solid interfaces. Surf Sci 16:438

Xu H, Li M, He B (1995) Immobilization of Candida cylindracea lipase on methyl acrylate-divinyl benzene copolymer and its derivatives. Enzyme Microb Technol 17:194-199

Yildiz Y, Pamuk H, Karatepe O et al (2016a) Carbon black hybrid material furnished monodisperse Platinum nanoparticles as highly efficient and reusable electrocatalysts for formic acid electro-oxidation. RSC Adv 6:32858-32862

Yildiz Y, Ulus R, Eris S et al (2016b) Functionalized multi-walled carbon nanotubes (f-MWCNT) as highly efficient and reusable heterogeneous catalysts for the synthesis of acridinedione derivatives. Chem Select 1(13):3861-3865

Yildiz Y, Erken E, Pamuk H et al (2016c) Monodisperse Pt nanoparticles assembled on reduced graphene oxide: highly efficient and reusable catalyst for methanol oxidation and dehydrocoupling of dimethylamine-borane (DMAB). J Nanosci Nanotechnol 16:5951-5958

Yildiz Y, Esirden I, Erken E et al (2016d) Microwave (Mw)-assisted Synthesis of 5-substituted $1 \mathrm{H}$-tetrazoles via [3+2] cycloaddition catalyzed by $\mathrm{Mw}-\mathrm{Pd} / \mathrm{Co}$ nanoparticles decorated on multi-walled carbon nanotubes. Chem Select 1(8):1695-1701

Yildiz Y, Okyay TO, Gezer B et al (2016e) Monodisperse Mw-Pt NPs@VC as highly efficient and reusable adsorbents for methylene blue removal. J Cluster Sci 27:1953-1962

Yildiz Y, Kuzu S, Sen B et al (2017a) Different ligand based monodispersed metal nanoparticles decorated with rGO as highly active and reusable catalysts for the methanol oxidation. Int J Hydrogen Energy 42(18):13061-13069

Yildiz Y, Onal Okyay T, Sen B et al (2017b) Activated carbon furnished monodisperse Pt nanocomposites as a superior adsorbent for methylene blue removal from aqueous solutions. J Nanosci Nanotechnol 17:4799-4804

Yildiz Y, Okyay TO, Sen B et al (2017c) Highly monodisperse Pt/Rh nanoparticles confined in the graphene oxide for Highly efficient and reusable sorbents for methylene blue removal from aqueous solutions. Chem Select 2(2):697-701

Zhang J, Landry MP, Barone PW, Sen F (2013) Molecular recognition using corona phase complexes made of synthetic polymers adsorbed on carbon nanotubes. Nat Nanotechnol 8(12):959-968

Publisher's Note Springer Nature remains neutral with regard to jurisdictional claims in published maps and institutional affiliations. 